\title{
The Hybrid Research Method Used for (Un)Planned Bratislava Examination and Interpretation
}

\section{Ing. arch. Monika BOČKOVÁ}

Tutor: prof. Dr. Ing. arch. Henrieta Moravčíková; Ústav urbanismu, Ústav dejín a teórie architektúry a obnovy pamiatok, Fakulta architektúry, STU v Bratislave, Slovenská republika E-mail address: monika.bockova@stuba.sk

\begin{abstract}
This paper describes the hybrid method used in the (Un)Planned Bratislava research (2019). The city of Bratislava was analysed as a permanently open work consisting of layers of fragmentary built visions. Part of this research was based on the visual interpretation of archive findings in the spatial context. The use of architectural digital tools allowed new complex comprehension of the issue. Various visualisations of selected locations helped to reveal new causalities in the history of their development.
\end{abstract}

KEYWORDS: Bratislava; urban planning; history; hybrid research method

\section{The Hybrid Research Method Used for (Un)Planned Bratislava Exami- nation and Interpretation}

The research of the history of urban planning in the city of Bratislava was initiated by a need for a wider comprehension of the problems faced when planning and building cities, which became more apparent with growing criticisms of the current situation concerning crucial changes. Even brief glimpses into the past indicated that the first precondition for addressing this situation would be an analysis of the history of planning and construction in Bratislava, particularly the era of modern urban planning from the end of the 19th century to the present. From the start, it was no less clear that this task offered the chance for 
a far more ambitious treatment than a standard historiography. The research was guided by Henrieta Moravčíková and the members of the research team were Katarína Haberlandová, Laura Krišteková and Peter Szalay from the Department of Architecture at the History Institute, Slovak Academy of Sciences, and myself, Monika Bočková from the Faculty of Architecture of the Slovak Technical University.

The goal of the research was to draw attention to the history of modern planning in Bratislava, uncover and describe the relation between planning and construction, define the architectonic-urbanistic conceptions and paradigms relevant with regard to the urban structure of Bratislava, and to examine selected instances of their application in the material structure of the city, using them as a base to reveal the laws of their development. We tried to specify the characteristic urban structures, architectonic forms and situations that determine the city today. The knowledge thus acquired could serve as a reference point in the process of examining and working with the urban structure, as much in a retrospective as a future-oriented sense. The basis for the research was the idea of the unplanned city.

In our research into the modern planning and construction of Bratislava, we applied a methodological approach consisting of a hybrid combination of the methods of architectonic, urbanistic and architectural historical qualitative research and the visualisation technologies of architecture and planning. With the aim of improving our understanding of the relationship between planned and realised city building and the mechanism of its functioning, we confronted the factual findings from the history of planning and construction with visualisations of the planned (and realised) interventions in the urban structure. In this process, we concentrated on the findings from the crucial urban plans and the conditions that shaped them. This method similarly allowed for the identification, abstraction and visualisation of key inserts into the urban tissue and its changes over the course of more than a hundred years.

My contribution to the research concerned the digitalisation of dozens of historic blueprints and the construction of both $2 \mathrm{D}$ and $3 \mathrm{D}$ models of realised and unrealised interventions in the urban structure. Essential to this component was the use of the partial digital model of Bratislava accessible from open sources, which we supplemented to include additional, previously unmodelled sections. The modelling was performed using the programs AutoCAD, ArchiCAD and Sketchup, taking either axonometry or isometry as the basic depiction tool. In identifying the differences between planned and realised construction, we used layering of 2D and 3D models, sketches, historic cadastral maps and collages. For the construction of this visual narrative, a vital role was held by periodisation, i.e. depicting selected points of the urban structure at the time of their most historically-significant transformations. This hybrid method demanded the acquisition 
of extensive quantities of data, as well as the critical evaluation and interpretation thereof.

A specifically indispensable source of findings included, beyond the architectural-historiographic publications, archival materials and historic periodicals. The most essential sources of knowledge have been the holdings of the Archive of the City of Bratislava and of the City Museum. Registers of the minutes from city council meetings, records of approval hearings for construction regulations, building permits, cadastral maps, collections of photographs and postcards, city regulatory plans or regulatory blueprints for individual streets, alongside materials from architectural and planning competitions including the set conditions, competition entries or minutes from the competition juries, were vital for constructing our image of the planned and real form of the city in the past.

Using this method, we were able to bring together and put into coherent form a wide range of materials from varying sources and periods, which previously had never been connected. At the very least, they were placed together for the very first time in digital form. On the basis of this corpus, we then compiled actual and potential developmental models for selected parts of the urban structure, allowing for a comparative investigation of the current form of Bratislava's structure with respect to its planned and its factual historic development. Quite literally, it implied making invisible history visible, connecting local manifestations across history, revealing their mutual ties and links to city-wide tendencies to make their correlation evident and understandable. As became clear, the connection of historiography and technical engineering disciplines such as architecture and urban planning, along with their digital visualisation methods, made it possible to reveal otherwise unobservable laws and opened the possibility for new and more complex conceptualisation of the problems in the history of urban planning and construction.

The hybrid method of examining urban structures was then verified successively in several case studies. In investigating the start of modern planning in Bratislava and its impact on the current form of the city, we visualised and compared three conceptions for construction regulation, with the later development of the urban structure and its present appearance evaluating the current urban development of Bratislava. In the process of investigating the planning and construction of Bratislava, evaluation and comparison with the extant urban structure, we managed to identify within the structure of Bratislava several urban-planning situations that could be described as characteristic of the city. These situations are marked by a certain tension arising from the confrontation of the organic development of the urban structure with modern planning methods, and the relationship between traditional historic urban spaces and elements of modern urban design. Most of these situations are repeated in the urban structure, though several are nonetheless unique and connected to the one individual locality. Through their analysis and classification, we arrived at a portfolio of several typological situations. Our aim of connecting 
the standpoint of urban morphology with the perspective of phenomenology was most closely matched by the Catalan architect and urban planner Ignasi de Solà-Morales. Based on his theoretical work, we applied and elaborated the categories of urban mutation, flow, terrain vague, habitation and container.

Although the research method was specified at the beginning of the project, it opened up other possibilities for us during research. The use of digital technologies allowed us to more accurately compare individual plans, visions and time sections by digitizing numerous drawings, while it was possible to examine phenomena on a scale of the entire city, up to individual sites. Last but not least, this method offered us a clear way of presenting the acquired knowledge, which would otherwise remain only in text form.

\section{Literature}

Moravčíková, Henrieta - Szalay, Peter - Haberlandová, Katarína - Krišteková, Laura Bočková, Monika: (Ne)plánovaná Bratislava. Bratislava, Veda, 2019.

De Solà-Morales, Ignasi: Present and Futures. Architecture in Cities. In: Present and Futures. Architecture in Cities. Exhibition catalogue. De Solà-Morales, I. and Costa, X. (eds). Barcelona, Actar, 1996, pp. 10-23.

Rossi, Aldo: L'architettura della città. Padova, Marsilio, 1966. Lynch, Kevin: The Image of the City. Cambridge MA, MIT Press, 1960.

Eco, Umberto: Opera aperta, Milano, Bompiani, 1967.

Pier Vittorio Aureli: The Possibility of an Absolute Architecture, Cambridge, MIT Press, 2011.

Blau, Eve - Rupnik, Ivan: Project Zagreb. Barcelona, Actar, 2007. 

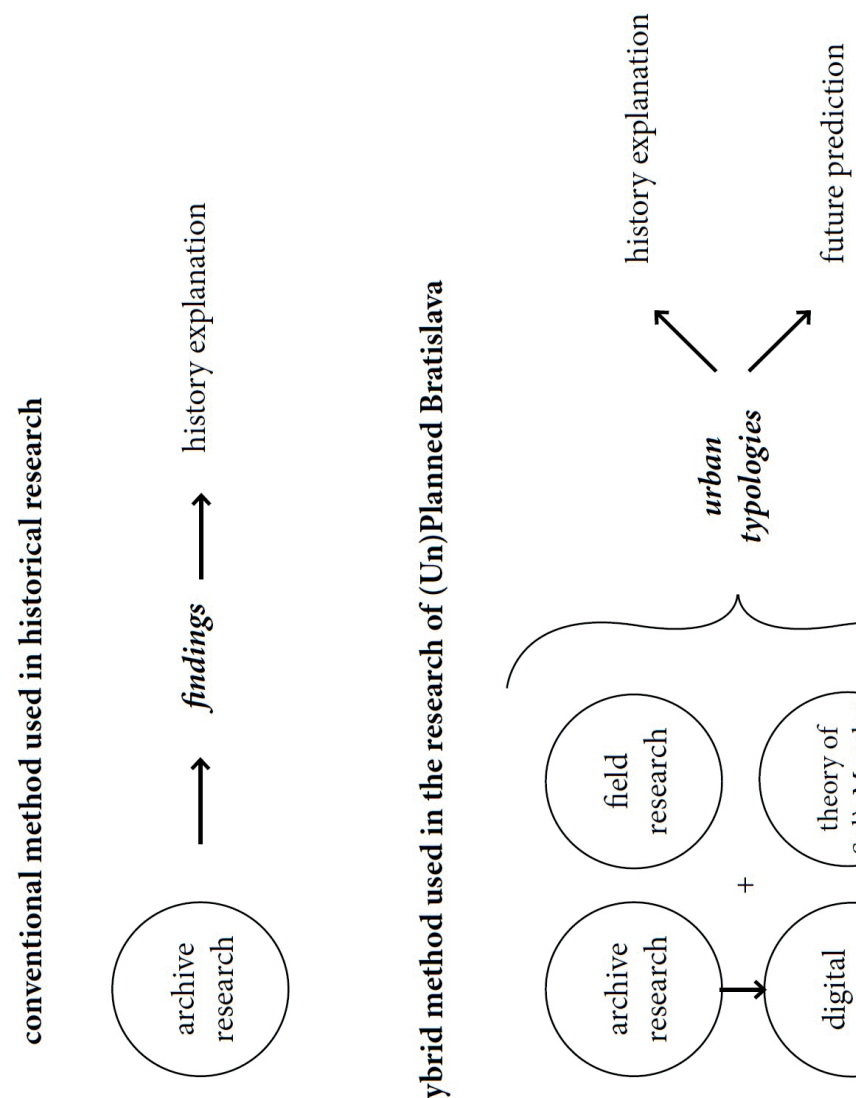

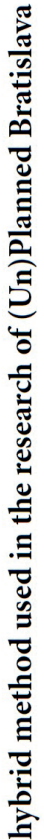
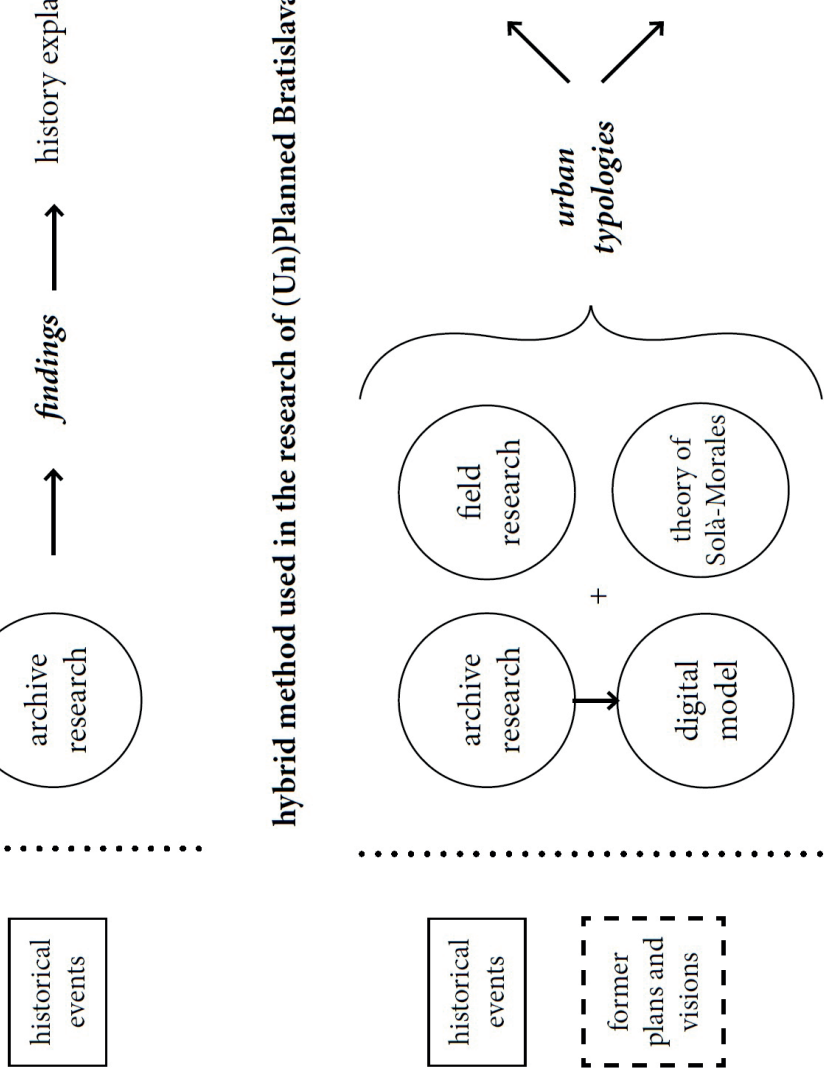

Fig. 1. The comparison of conventional and hybrid method (source: Monika Bočková) 


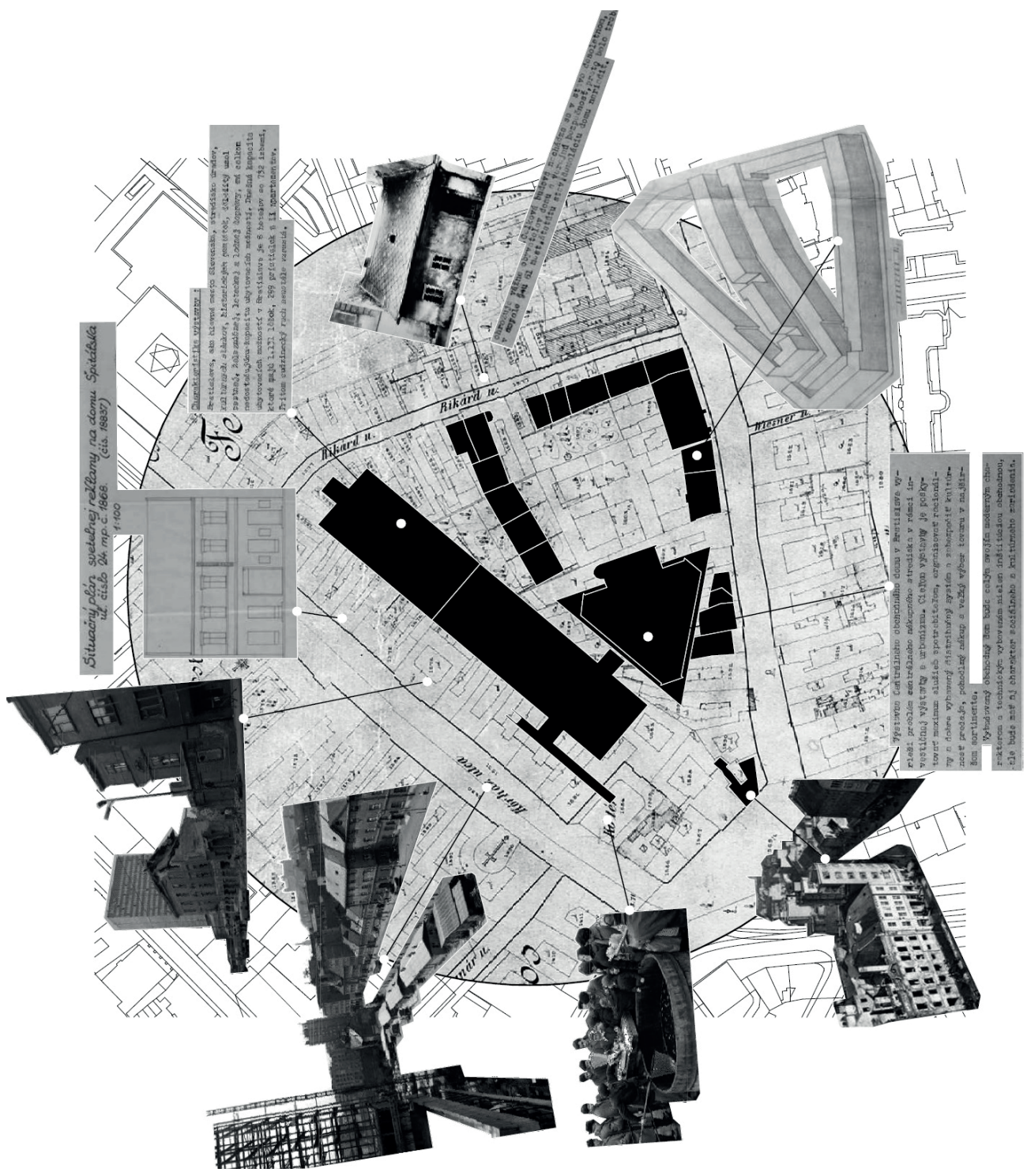

Fig. 2. Case study: Kamenné námestie, layering of cadastral maps and archive documents (source: Monika Bočková) 


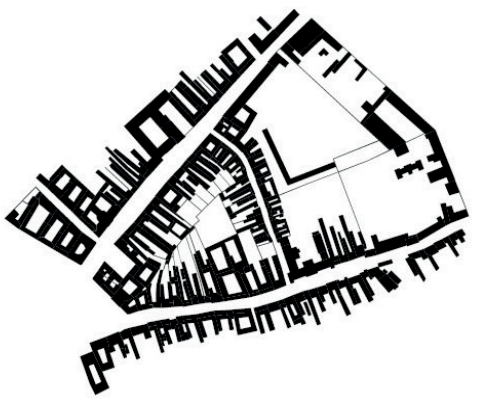

1990

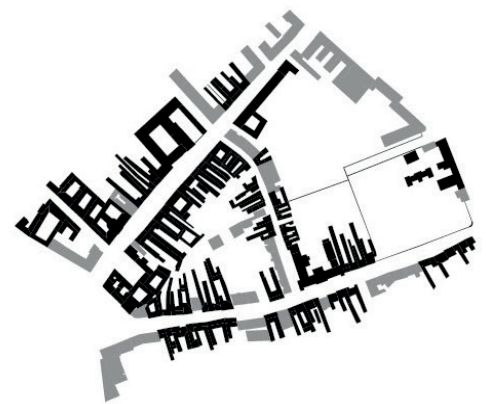

impact of regulation on new construction

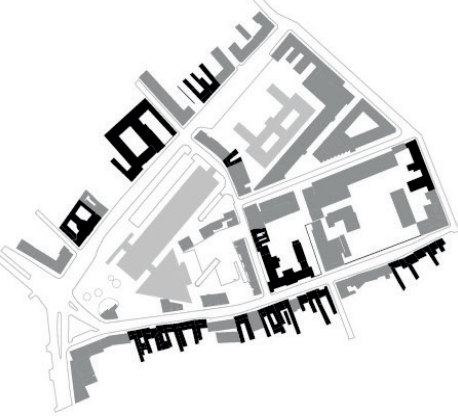

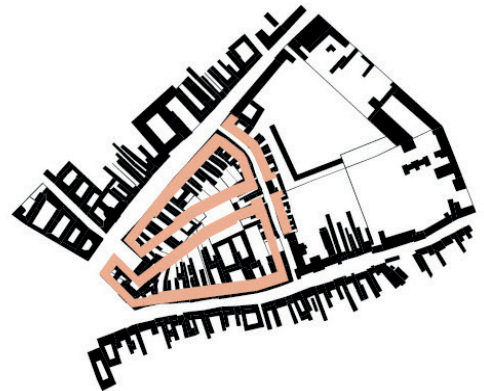

regulation and construction guidelines, 1934

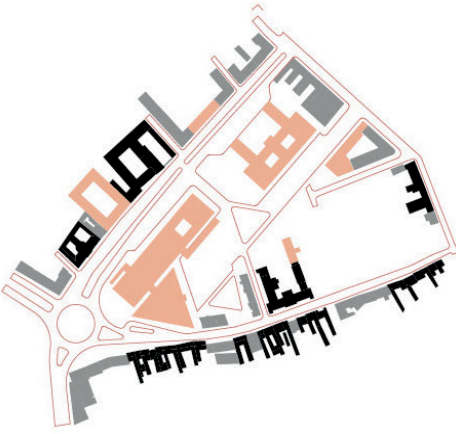

competition proposal for commercialsocial centre and administrative complex, I.Matušík, 1969

Fig. 3. Case study: Kamenné námestie, the evolution of the urban structure and the plans for its transformation compared in 2D (source: Monika Bočková) 

and Interpretation, Ing. arch. Monika Bočková

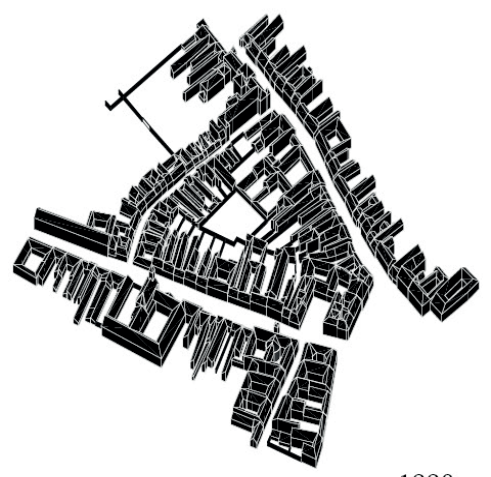

1990
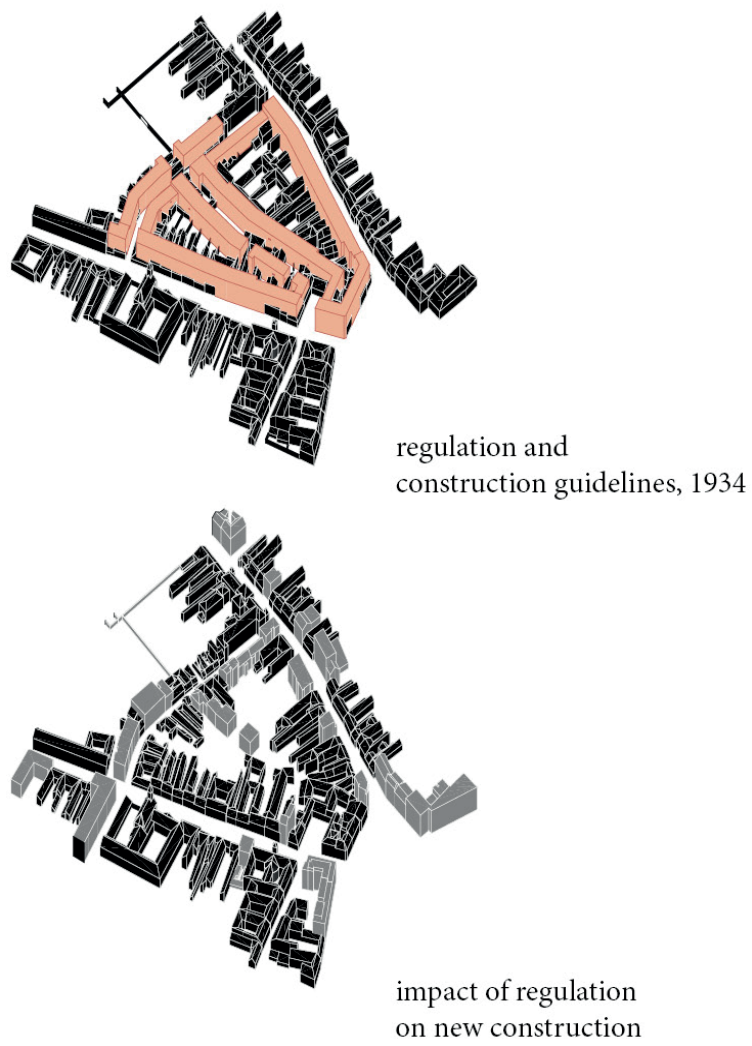

Fig. 4. Case study: Kamenné námestie, the evolution of urban structure in the first half of 20th century visualised in 3D (source: Monika Bočková) 


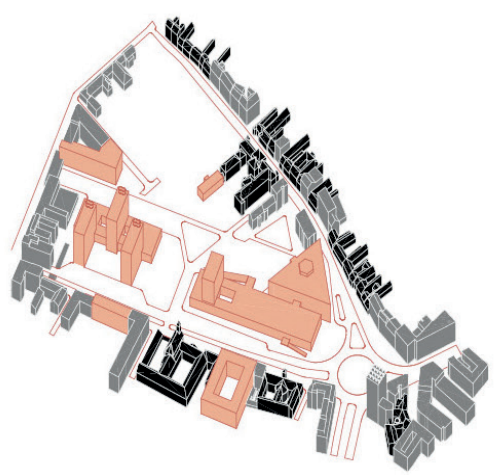

competition proposal for commercial-

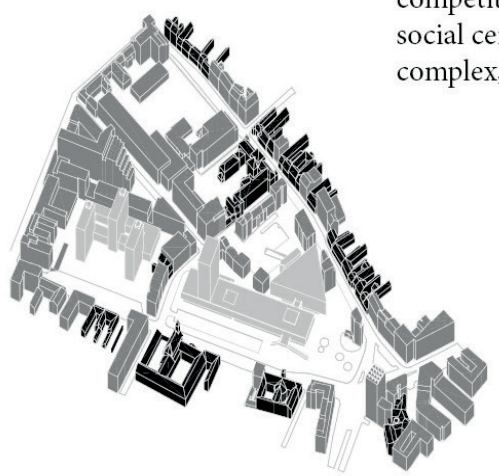

2019

Fig. 5. Case study: Kamenné námestie, the evolution of urban structure in the second half of 20th century visualised in 3D (source: Monika Bočková) 